\title{
ANOTHER VIEW ON THE OPTIMIZATION OF THE BRAYTON CYCLE WITH RECUPERATOR
}

\author{
Marija Živić, Zdravko Virag, Antun Galović
}

Original scientific paper Nondimensional expressions for the work output, thermal efficiency, heat input, and entropy generation number in the Brayton cycle with a recuperator are given as functions of seven input parameters: pressure ratio, temperature ratio, recuperator effectiveness, turbine and compressor isentropic efficiencies, nondimensional pressure drop in the combustor and recuperator and the ratio of specific heat capacities. The expressions for pressure ratios which maximize or minimize the considered quantities are derived. Since it is not possible to maximize all the quantities at a unique value of pressure ratio, three optimization criteria: (i) maximum work output, (ii) maximum thermal efficiency, and (iii) maximum of their weighted sum are defined. For each criterion two diagrams from which one can select optimal pressure ratio and read out all basic quantities defining the Brayton cycle are provided. In the case of criterion of maximum thermal efficiency, when the recuperator effectiveness is lower than the certain limit, the Brayton cycle without a recuperator is better than that with it. In the case of other two criteria, the Brayton cycle with a recuperator is always better than that without it, regardless of the value of the recuperator effectiveness.

Keywords: Brayton cycle; design domain; entropy analysis; optimization

Drugačiji pogled na optimizaciju Braytonovog ciklusa s rekuperatorom

Izvorni znanstveni članak

Bezdimenzijski izrazi za rad, termički stupanj djelovanja, dovedenu toplinu i značajku entropijske produkcije u Braytonovom ciklusu s rekuperatorom su prikazani kao funkcije sedam ulaznih parametara: omjer tlakova, omjer temperatura, efikasnost rekuperatora, izentropski stupnjevi djelovanja kompresora i turbine, bezdimenzijski pad tlaka u komori za izgaranje i rekuperatoru te izentropski koeficijent. Izvedeni su izrazi za omjere tlakova koji maksimiziraju ili minimiziraju razmatrane veličine.Budući da nije moguće maksimizirati sve veličine pri jednoj vrijednosti omjera tlakova, definirana su tri kriterija optimizacije: (i) maksimalni rad, (ii) maksimalni termički stupanj djelovanja i (iii) maksimum njihove težinske sume. Za svaki kriterij dana su dva dijagrama iz kojih se može odabrati optimalni omjer tlakova i očitati sve osnovne veličine koje definiraju Braytonov ciklus. U slučaju kriterija maksimalnog termičkog stupnja djelovanja, kada je efikasnost rekuperatora manja od određene vrijednosti, Braytonovo ciklus bez rekuperatora je bolji nego onaj s rekuperatorom. U slučaju ostala dva kriterija, Braytonov ciklus s rekuperatorom je uvijek bolji od onog bez rekuperatora, bez obzira na vrijednost efikasnosti rekuperatora.

Ključne riječi: Braytonov ciklus; dizajn domena; entropijska analiza; optimizacija

\section{Introduction}

Global warming caused by increased emissions of greenhouse gases is a major environmental problem nowadays to which power generation contributes greatly. Gas turbines operate using the Brayton cycle, which may be a simple one when it is used for limited peak power generation, or there may be various variants of advanced Brayton cycle now increasingly used for the base load applications. Although the gas turbine has many advantages, the simple cycle thermal efficiency is limited to about $40 \%$. It is very important to increase the thermal efficiency of power generation since higher efficiency means a lower amount of harmful gases for a given power output. Possible ways to increase the thermal efficiency at a given turbine inlet temperature using the wasted heat in: (i) a regenerative process (ii) combined gas-steam cycles and (iii) cogeneration, i.e. combined heat and power processes.

A great number of optimizations of the Brayton cycle have been carried out and the gas turbine engine design parameters have been obtained. The optimization criterion used has been either the maximum power output $[1,2,3]$ or the maximum thermal efficiency, depending on the purpose and operating conditions of the engine. The criterion of maximum thermal efficiency is favourable in stationary power plants because the ratio of the fuel consumption to the gained power output will be the most favourable. In some cases, like in airplane take-off, the criterion of maximum power will provide maximal thrust from the available engine. For example, in ship propulsion systems, both fuel consumption and thrust gain may be equally important, and in this case, both the maximum power and the maximum thermal efficiency criterion have to be considered in the design [4].

Bejan [5] analysed a simple, closed, endoreversible Brayton cycle and combined the criteria of the maximum power output and the minimum entropy generation to optimize the sizes of the hot- and cold-side heat exchangers. Salamon et al. [6] discussed the equivalence of the optimization objectives: minimizing entropy production and maximizing power production. $\mathrm{Wu}$ et al. [7] studied an endoreversible Brayton cycle with regeneration through the power output analysis, which was focused on minimizing irreversibilities associated with the hot- and cold-side heat exchangers and the recuperator. Cheng and Chen [8] investigated the effect of regeneration on the power output and thermal efficiency in an endoreversible, regenerative Brayton cycle. They calculated the maximum power output and the corresponding thermal and the second law efficiencies using the optimal values of cycle temperatures. Medina, Roco, and Hernandez [9] applied the method of power density maximization (output power per maximum specific volume in the cycle) to regenerative gas turbines and showed that the thermal efficiency at the maximum power density may be greater or smaller than the thermal efficiency at the maximum power output depending on the value of the recuperator effectiveness.

Chen et al. [10] performed a theoretical analysis of a closed, regenerative, internally irreversible Brayton cycle with variable temperature heat reservoirs. Wang et al. [11] 
derived analytical expressions of the dimensionless power and the thermal efficiency of an irreversible, closed, intercooled regenerative Brayton cycle coupled to variable temperature heat reservoirs. Optimization was carried out to find optimal values of the total and the intercooling pressure ratio that gives the maximum power output and the maximum thermal efficiency. Tayagi et al. [12] gave analytical relations of the dimensionless power output and the corresponding thermal efficiency for the irreversible, regenerative intercooled-reheat Brayton cycle coupled to variable temperature heat reservoirs. SanchezOrgaz et al. [13] developed a theoretical model of a multistep, regenerative, closed Brayton cycle with an arbitrary number of intercooled compression steps and reheated expansion steps. They used both the maximum power output and the maximum thermal efficiency optimization objective. Ust et al. [14, 15] performed an ecological optimization on the endoreversible and the irreversible regenerative Brayton heat-engine model. The effects of the recuperator effectiveness on the global and optimal performances were investigated and the results were compared with those for the maximum power output criterion. Recently, Durmusoglu and Ust [16] optimized an irreversible, regenerative, closed Brayton cycle using a thermoeconomic objective criterion which is defined as the ratio of net power output to the total cost rate.

Haseli [17] performed an analysis of the regenerative, open Brayton cycle and its optimization on the basis of the maximization of work output and thermal efficiency and the minimization of entropy generation. He suggested the second law efficiency optimization as a trade-off between the maximum work output and the maximum first law efficiency optimization.

The goals of this study are: to summarize the optimization with respect to three different thermodynamic criteria by using two concise diagrams for each criteria, and to point out that, depending on recuperator effectiveness, the regenerative Brayton cycle could be thermally less efficient than the one without recuperator.

\section{Energy analysis of a regenerative Brayton cycle}

Schematic representation of an open Brayton cycle with heat regeneration is shown in Fig. 1 and its qualitative $T-S$ diagram in Fig. 2. Irreversible adiabatic processes in the compressor are represented by the line between points 1 and 2, heating of working fluid in the recuperator by the line from point 2 to 3 , combustion by the line from 3 to 4 , irreversible adiabatic expansion in the turbine by the line from 4 to 5 , and cooling of the exhaust gas in the heat recuperator by the line from 5 to 6 . Auxiliary lines from point 1 to $2^{\text {is }}$ and from $4-5^{\text {is }}$ represent ideal (isentropic) processes in the compressor and the turbine, respectively.

The temperatures $T_{2}$ and $T_{5}$ can be expressed by means of the isentropic efficiency of the compressor and turbine as:

$$
T_{2}=T_{1}\left[1+\frac{1}{\eta_{\mathrm{c}}}\left(\left(\frac{p_{2}}{p_{1}}\right)^{\alpha}-1\right)\right]
$$

$$
T_{5}=T_{4}\left[1-\eta_{\mathrm{t}}\left(1-\left(\frac{p_{5}}{p_{4}}\right)^{\alpha}\right)\right]
$$

where $\eta_{\mathrm{c}}$ and $\eta_{\mathrm{t}}$ are compressor and turbine isentropic efficiency, respectively.

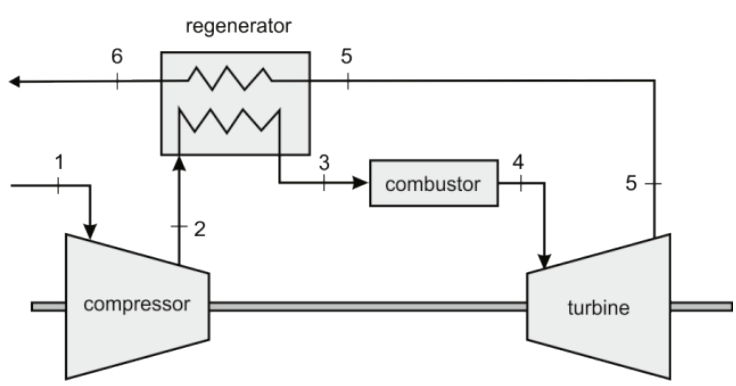

Figure 1 Shematic representation of a Brayton cycle with heat regeneration

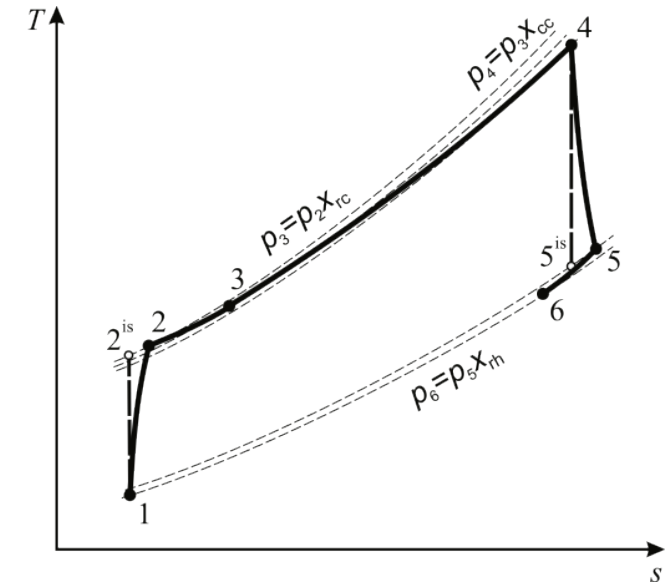

Figure 2 Qualitative $T-s$ diagram of a Brayton cycle with heat regeneration

Pressure leaving the recuperator and combustion chamber is defined by the following expressions:

$p_{3}=p_{2} x_{\mathrm{rc}}, p_{4}=p_{3} x_{\mathrm{cc}}, p_{6}=p_{5} x_{\mathrm{rh}}$

where $x_{\mathrm{rc}}, x_{\mathrm{rh}}, x_{\mathrm{cc}}$ are nondimensional pressure drop in cold side of recuperator, in hot side of recuperator, and in the combustor, respectively.

The temperature $T_{3}$ is defined by the effectiveness $(\varepsilon)$ of the recuperator in the form

$T_{3}=T_{2}+\varepsilon\left(T_{5}-T_{2}\right)$

while the temperature $T_{6}$ can be determined from the energy balance for the recuperator

$T_{6}=T_{5}-\left(T_{3}-T_{2}\right)$

Using the above equations, Eq. (5) can be easily modified into the following form:

$T_{6}=T_{4}\left(1-\eta_{\mathrm{t}}\left(1-\left(\frac{1}{r_{p} x}\right)^{\alpha}\right)\right)$ 
where $r_{p}=p_{2} / p_{1}$ is pressure ratio and $x=x_{\mathrm{cc}} \cdot x_{\mathrm{rc}} \cdot x_{\mathrm{rh}}$ is total nondimensional pressure drop.

\subsection{Work output}

The dimensionless work output is given by the following equation:

$$
w=\frac{q_{\text {in }}-q_{\text {out }}}{c_{p} T_{1}}=\frac{\left(T_{4}-T_{3}\right)-\left(T_{6}-T_{1}\right)}{T_{1}}
$$

where $q_{\text {in }}$ and $q_{\text {out }}$ are the specific heat input and output, $(\mathrm{J} / \mathrm{kg})$, respectively and $c_{p}$ is the specific heat capacity, $\left(\mathrm{Jkg}^{-1} \mathrm{~K}^{-1}\right)$.

By introducing $r_{T}=T_{4} / T_{1}$, Eq. (7) takes the following dimensionless form:

$$
w=\frac{1-r_{p}^{\alpha}}{\eta_{\mathrm{c}}}+\eta_{\mathrm{t}} r_{T}\left(1-\left(\frac{1}{x r_{p}}\right)^{\alpha}\right)
$$

where $\alpha=(\kappa-1) / \kappa$ and $\kappa$ is the ratio of specific heat capacities.

It can be shown that the dimensionless work output has its maximum at the optimal pressure ratio defined by the following expression:

$$
r_{p_{-} w \max }=\sqrt{\frac{\left(\eta_{\mathrm{c}} \eta_{\mathrm{t}} r_{T}\right)^{\frac{1}{\alpha}}}{x}}
$$

and the maximum is defined by

$$
w_{\max }=\frac{x^{\frac{\alpha}{2}}\left(\eta_{\mathrm{c}} \eta_{\mathrm{t}} r_{T}+1\right)-2\left(\eta_{\mathrm{c}} \eta_{\mathrm{t}} r_{T}\right)^{\frac{1}{2}}}{\eta_{\mathrm{c}} x^{\frac{\alpha}{2}}}
$$

\subsection{Heat input and heat output per cycle and the cycle thermal efficiency}

The dimensionless expression for the heat input is

$$
\begin{aligned}
q=\frac{T_{4}-T_{3}}{T_{1}}= & r_{T}-(1-\varepsilon)\left(1+\frac{r_{p}^{\alpha}}{\eta_{\mathrm{c}}}\right)- \\
& \varepsilon r_{T}\left[1-\eta_{\mathrm{t}}\left(1-\left(x r_{p}\right)^{-\alpha}\right)\right]
\end{aligned}
$$

It can be shown that the heat input has its maximum at a certain pressure ratio defined by

$$
r_{p_{-} q \max }=\sqrt{\left(\frac{\eta_{\mathrm{c}} \eta_{\mathrm{t}} r_{T} \varepsilon}{1-\varepsilon}\right)^{\frac{1}{\alpha}} \frac{1}{x}}
$$

$q_{\max }=\frac{1}{\eta_{\mathrm{c}}}\left\{\begin{array}{l}r_{T} \eta_{\mathrm{c}}\left[1-\varepsilon\left(1-\eta_{\mathrm{t}}\right)\right]+ \\ (1-\varepsilon)\left(1-\eta_{\mathrm{c}}\right)-2 \sqrt{\frac{r_{T} \eta_{\mathrm{c}} \eta_{\mathrm{t}} \varepsilon(1-\varepsilon)}{x^{\alpha}}}\end{array}\right\}$

It is obvious from Eqs. (9) and (12) that in the general case, the work output and the heat input reach the maximum at different values of $r_{p}$. The ratio between $r_{p \_q \max }$ and $r_{p_{-} w \max }$ is equal to $\sqrt{[\varepsilon /(1-\varepsilon)]^{1 / \alpha}}$, so it is clear that at $\varepsilon=0,5 r_{p_{-} q \max }=r_{p_{-} w \max }$, for $\varepsilon>0,5 \quad r_{p_{-} q \max }>r_{p_{-} w \max }$ and for $\varepsilon<0,5 r_{p_{q} q \max }<r_{p_{-} w \max }$.

For $\varepsilon=0$, the heat input does not show the maximum. Heat output is defined by

$$
\begin{aligned}
q_{0}=\frac{T_{6}-T_{1}}{T_{1}} & =r_{T}(1-\varepsilon)\left[1-\eta_{\mathrm{t}}\left(1-\left(\frac{1}{x r_{p}}\right)^{\alpha}\right)\right] \\
& +\varepsilon\left(1+\frac{r_{p}^{\alpha}-1}{\eta_{\mathrm{c}}}\right)-1
\end{aligned}
$$

The thermal efficiency of the cycle is

$\eta=\frac{q-q_{0}}{q}=\frac{w}{q}$

where $w$ and $q$ are defined by Eqs. (8) and (11), respectively. It can be shown that the thermal efficiency has its maximum at a certain pressure ratio $r_{p_{-} \eta \max }$, as defined in [17].

When analysing entropy generation during an endoreversible cycle, it is sufficient to consider only the heat reservoirs. Here, we assume that the heat source is at the temperature $T_{\text {hot }}=T_{4}$ and the heat sink is at $T_{\text {cold }}=T_{1}$. In that case, the entropy generation number is

$$
N_{s}=-\frac{q}{c_{p} T_{4}}+\frac{q_{0}}{c_{p} T_{1}}=\frac{q_{0}}{c_{p} T_{1}}-\frac{1}{r_{T}} \frac{q}{c_{p} T_{1}}
$$

or, expressed in terms of previously selected parameters, it is

$$
\begin{aligned}
N_{s} & =\left(1+\frac{r_{p}^{\alpha}-1}{\eta_{\mathrm{c}}}\right)\left[\varepsilon+\frac{1}{r_{T}}(1-\varepsilon)\right] \\
& +r_{T}\left[\varepsilon\left(\frac{1}{r_{T}}-1\right)+1\right]\left\{1-\eta_{\mathrm{t}}\left[1-\left(\frac{1}{x r_{p}}\right)^{\alpha}\right]\right\} \\
& +r_{T}(1-\varepsilon)\left(\frac{1}{r_{T}}+1\right)-1
\end{aligned}
$$

It can be shown that the entropy generation number shows its minimum at the pressure ratio $r_{p-N s m i n}$ (when all other parameters are kept constant) defined by

and the maximum is defined by 
$r_{p_{-} N \text { smin }}=\sqrt{\left(\frac{\eta_{\mathrm{c}} \eta_{\mathrm{t}} r_{T}\left[r_{T}-\varepsilon\left(r_{T}-1\right)\right]}{1+\varepsilon\left(r_{T}-1\right)}\right)^{\frac{1}{\alpha}} \frac{1}{x}}$

It is obvious from Eqs. (9), (12), and (18) that for $\varepsilon=0,5$ all variables $\left(w, q, \eta\right.$ and $N_{\mathrm{s}}$ ) show their maximum at the same pressure ratio, as reported in [17].

\section{Results and discussion} are seven dimensionless variables: $r_{p}, r_{T}, \eta_{\mathrm{c}}, \eta_{\mathrm{t}}, \varepsilon, x$, and $\kappa$. Once the working fluid is chosen, $\kappa$ is constant, here $\kappa=1,4$. If one is interested in the maximum work output, maximum thermal efficiency or minimum entropy generation, it is necessary to examine the influence of all other six variables. It is physically clear that the maximum work output and the maximum thermal efficiency will be reached at as high as possible values of $x, \eta_{\mathrm{c}}, \eta_{\mathrm{t}}$, and $\varepsilon$ (the ideal case is when $x=\eta_{\mathrm{c}}=\eta_{\mathrm{t}}=\varepsilon=1$ ). In all the analysed cases that follow, we have assumed $\eta_{\mathrm{c}}=0,85$ and $\eta_{\mathrm{t}}=0,9$. For the pressure drop factors, we have assumed the following: (i) when $\varepsilon=0,9$, $x=x_{\mathrm{rh}} \cdot x_{\mathrm{rc}} \cdot x_{\mathrm{cc}}=0,85$, with $x_{\mathrm{rh}}=x_{\mathrm{rc}}=x_{\mathrm{cc}}$. (ii) for $\varepsilon<$ 0,9 , the heat transfer area of the recuperator is smaller, and we assumed that the pressure drop in the recuperator is also smaller, so we prescribed the next expression for pressure drop factors

$x_{\mathrm{rc}}=x_{\mathrm{rh}}=1-0,005859 \frac{\varepsilon}{1-\varepsilon}$

It is clear that $w, q$ and $\eta$ increase with the increase in $r_{\mathrm{T}}$, and their maximal values are obtained at the highest possible $r_{T}$.

For the selected values of $\kappa, x, \eta_{\mathrm{c}}, \eta_{\mathrm{t}}, \varepsilon$ and $r_{T}$, the values of $r_{p}$ which maximize $w, q$ and $\eta$, respectively are $r_{p_{-} w \max }, r_{p_{q} q \max }$, and $r_{p_{-} \eta \max }$; on the other hand, $r_{p_{-} N \mathrm{smin}}$ minimizes $N_{\mathrm{s}}$. The designer should decide which criterion or combination of criteria will be used to define the optimal solution. For example, in power plants, in which fuel consumption is the main concern, the maximum thermal efficiency is a desired criterion. On the other
In dimensionless Eqs. (8), (11), (15) and (17), there

hand, in the case of aeronautical vehicles where significant propulsion power is required during the takeoff, the maximum power output criterion is preferred. It is clear that the criterion of minimal $N_{s}$ is not very interesting for practical design since it results in low $w$ and $\eta$. The minimization of the ratio $N_{s} / w$ might be very useful since it searches for a solution which introduces minimal irreversibility per unit of obtained work. Using definitions (7), (15), and (16), this criterion can be expressed in the form

$$
\frac{N_{s}}{w}=\frac{\frac{q_{0}}{c_{p} T_{1}}-\frac{1}{r_{T}} \frac{q}{c_{p} T_{1}}}{\frac{q-q_{0}}{c_{p} T_{1}}}=\frac{1-\eta-\frac{1}{r_{T}}}{\eta}
$$

We can conclude from the above equation that for a given $r_{T}, N_{s} / w$ will reach the minimum at $\eta_{\max }$. In other words, the requirement of $\eta_{\max }$ is equivalent to the requirement of minimal entropy generation per work output.

In the following subsections, we are going to analyse three criteria: $w_{\max }, \eta_{\max }$, and $\left(w / w_{\text {ref }}+\eta / \eta_{\text {ref }}\right)_{\max }$ in the ranges $3 \leq r_{T} \leq 5$ and $0 \leq \varepsilon \leq 0,9$. Typical input design parameters are $r_{T}$ and $\varepsilon$; therefore, all results will be shown as functions of these two variables. From the results, one could choose the optimal $r_{p}$ and read out other relevant quantities (work output, thermal efficiency, heat input, and entropy generation number) for a selected cycle.

\subsection{Criterion $w_{\max }$}

Results for the case when the criterion is $w_{\max }$ are given in Fig. 3.

The left panel shows variations in $r_{p_{-} w \max }$ (black lines), $\eta$ (green lines) with $r_{T}$ and $\varepsilon$, and the right panel shows variations in $w_{\max }$ (black lines) and $q$ (red lines) with $r_{T}$ and $\varepsilon$. It is clear from Eqs. (11) and (12) that $\varepsilon$ does not influence $r_{p \_w \max }$ and $w_{\max }$; therefore, the lines in diagrams representing their variations are horizontal. Obviously $r_{p_{-} w \max }$ and $w_{\max }$ monotonically increase with the increase in $r_{T}$.
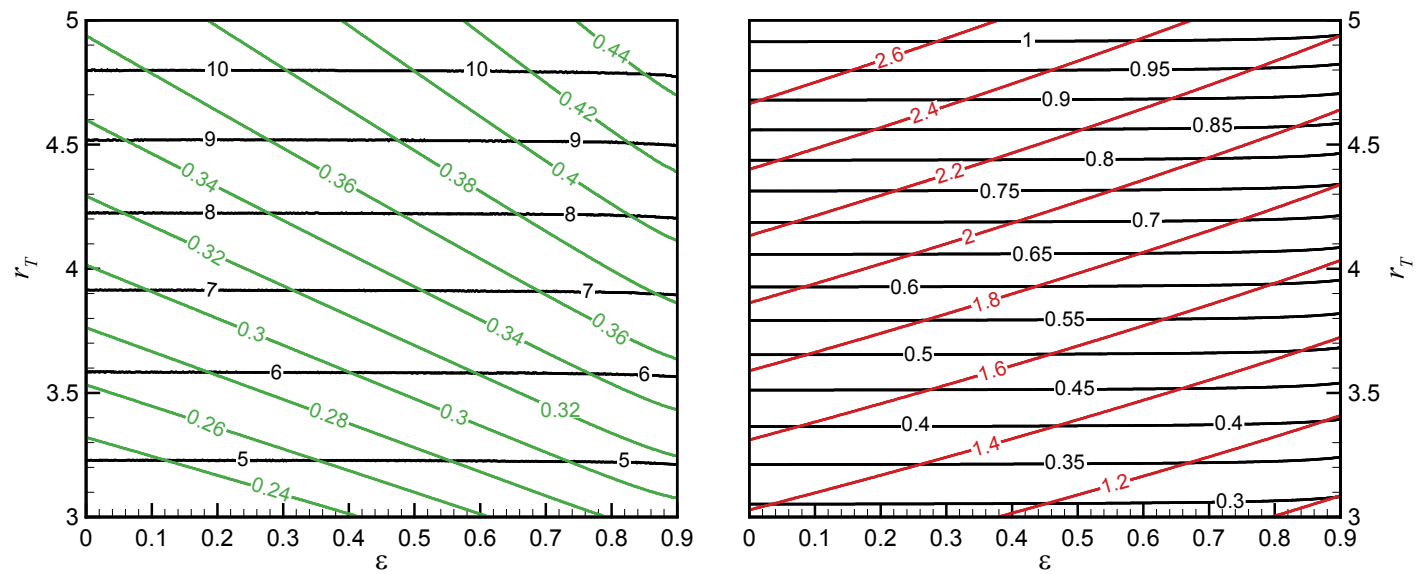

Figure 3 Diagrams for the case of $w_{\max }$ criterion. Left panel: variations in $r_{p_{-} \text {wmax }}$ (black lines) and $\eta$ (green lines) with $r_{T}$ and $\varepsilon$; Right panel: variations in $w$ (black lines) and $q$ (red lines) with $r_{T}$ and $\varepsilon$ 
Thermal efficiency increases with the increase in $r_{T}$ and $\varepsilon$, while the heat input increases with the increase in $r_{T}$ and decreases with the increase in $\varepsilon$. In this case, the same $w_{\max }$ could be obtained also without a recuperator, but $\eta$ is always greater in the case with a recuperator, regardless of its $\varepsilon$.

\subsection{Criterion $\eta_{\max }$ or $\left(N_{s} / w\right)_{\min }$}

Results for the case of $\eta_{\max }$ criterion are shown in Fig. 4. As in the previous case, for given $r_{T}$ and $\varepsilon$, Fig. 4. As in the previous case, for given $r_{T}$ and $\varepsilon$, these diagrams define the optimal $r_{p_{-}} \eta \max$, the obtainable $\eta_{\max }$ and $w$, as well as the necessary $q$. Some of the results can be found in [17], but Haseli's analysis is limited to $\varepsilon \geq 0,5$, while our results include the entire range of $\varepsilon$.
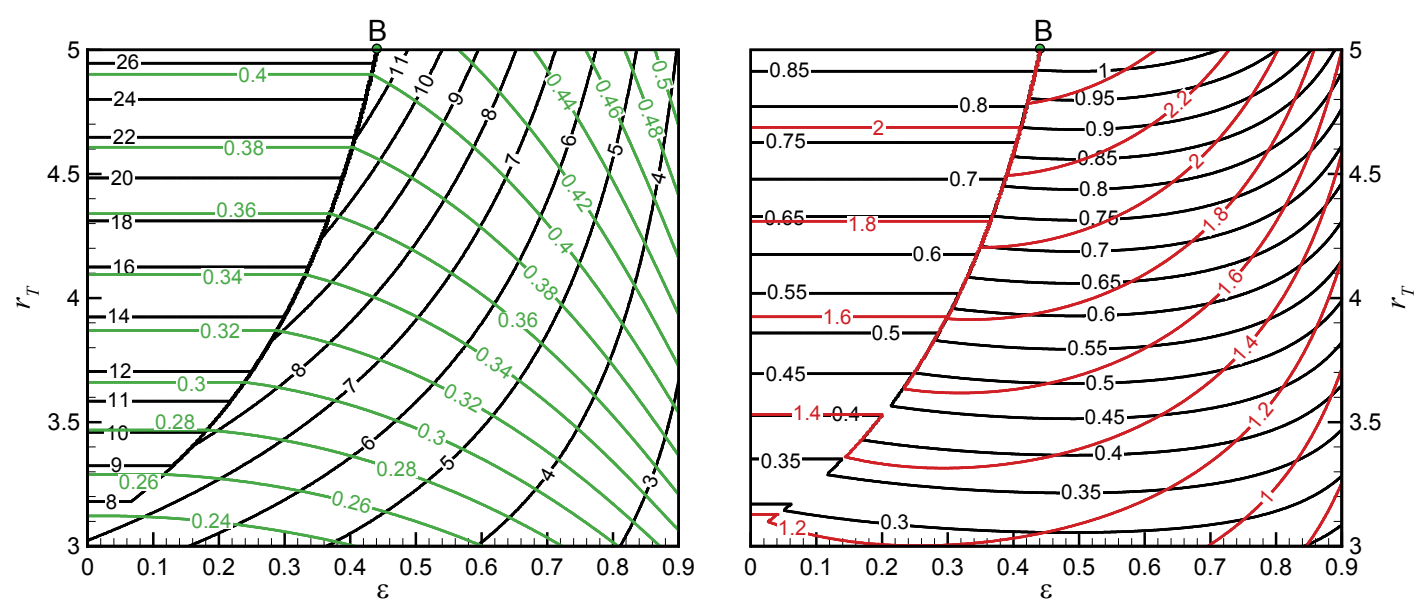

Figure 4 Diagrams for the case of $\eta_{\max }$ criterion. Left panel: variations in $r_{p \text { wmax }}$ (black lines) and $\eta$ (green lines) with $r_{T}$ and $\varepsilon$, Right panel: variations in $w$ (black lines) and $q$ (red lines) with $r_{T}$ and $\varepsilon$

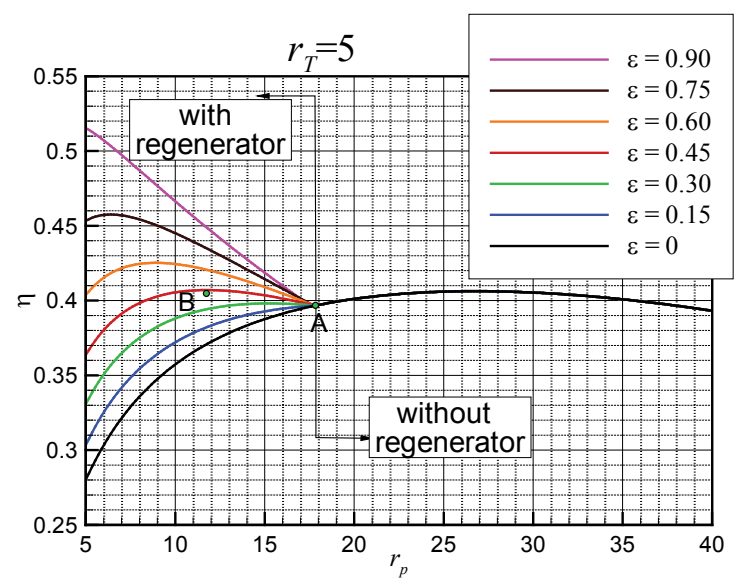

Figure 5 Variation in $\eta$ with $r_{p}$ and $\varepsilon$ at $r_{T}=5$

All Brayton cycles with recuperators converge to the Brayton cycle without a recuperator in the point A in Fig. 5 defined by $r_{p \mathrm{~A}}=17,8$. At this point, the outlet temperature from the compressor is the same as the outlet temperature from the turbine and for $r_{p}>r_{p_{-} \mathrm{A}}$ no technically useful solution exists for the Brayton cycle with a recuperator. This could be easily explained by the $T-s$ diagram presented in Fig. 6, which illustrates two Brayton cycles at $r_{T}=4,5$, one with a recuperator $(\varepsilon=0,15$ - blue line) and the other without a recuperator (green line).
It is interesting to note that there are two different domains in these diagrams. Looking at the left panel in Fig.4, the left hand side domain (with horizontal lines of $\eta_{\max }$ and $\left.r_{p} \eta_{\max }\right)$ represents the operating conditions for the Brayton cycle without a recuperator, meaning that in this domain it is possible to obtain a higher $\eta_{\max }$ without a $r_{p_{-} \eta \max }, w$, and $q$ at the border between these two domains, so the cycle without a recuperator requires higher $r_{p_{-} \eta \max }$ and results in a lower work output at a lower heat input. This is clear from Fig. 5 which shows the variation in $\eta$ with $r_{p}$ and $\varepsilon$, at $r_{T}=5$. In this figure, the black line represents the thermal efficiency of the Brayton cycle without a recuperator, and for this cycle, $\eta_{\max }=0,407$ has been reached at $r_{p} \eta \max =27$. recuperator than with it. Obviously, there are jumps in

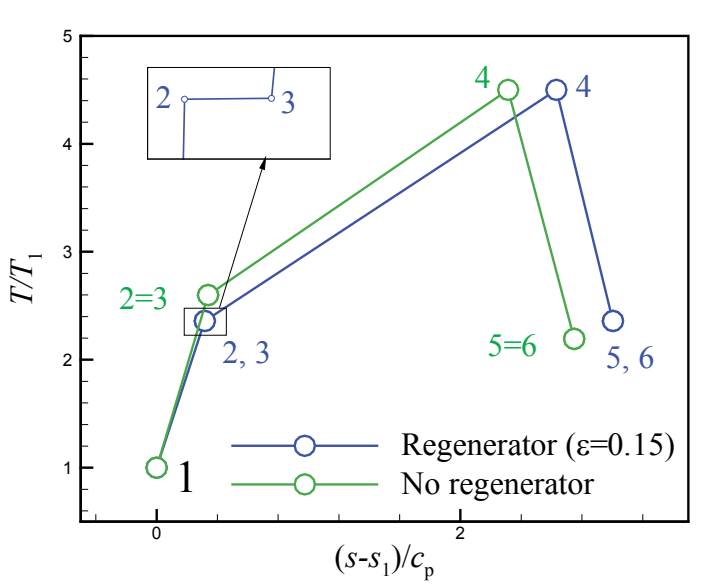

Figure 6 Schematic $T-s$ diagram of the Brayton cycle at $r_{T}=4.5$ with a recuperator (blue line) and without recuperator (green line)

Obviously, for the selected $r_{T}$ and $\varepsilon$, the operating point lies in the left hand side domain in Fig. 4, in which the process without a recuperator reaches a greater $\eta_{\max }$. In the Brayton cycle with a recuperator, there is a limit for temperature $T_{5}$ which must be higher than the temperature $T_{2}$. As can be seen in Fig. 5, the temperature $T_{2}$ is equal to the temperature $T_{3}$, which means that there is no heat exchange in the recuperator, but the pressure $p_{3}$ is lower than $p_{2}$ due to the pressure drop in the recuperator. The results for these two cases are: (i) the case with a recuperator $\eta_{\max }=0,365$, (at $\left.r_{p_{-} \eta \text { max }}=14,7\right), N_{s}=0,884$ and 
$w=0,781$, (ii) the case without a recuperator $\eta_{\max }=0,372$, (at $r_{p \_n \max }=20,17$ ), $N_{s}=0,771$ and $w=0,707$.

The point B in Fig. 5 is mapped in Fig. 4 and it lies at the border of the two domains at $r_{T}=5$. It could be concluded that at $r_{T}=5$ there is no need for a recuperator
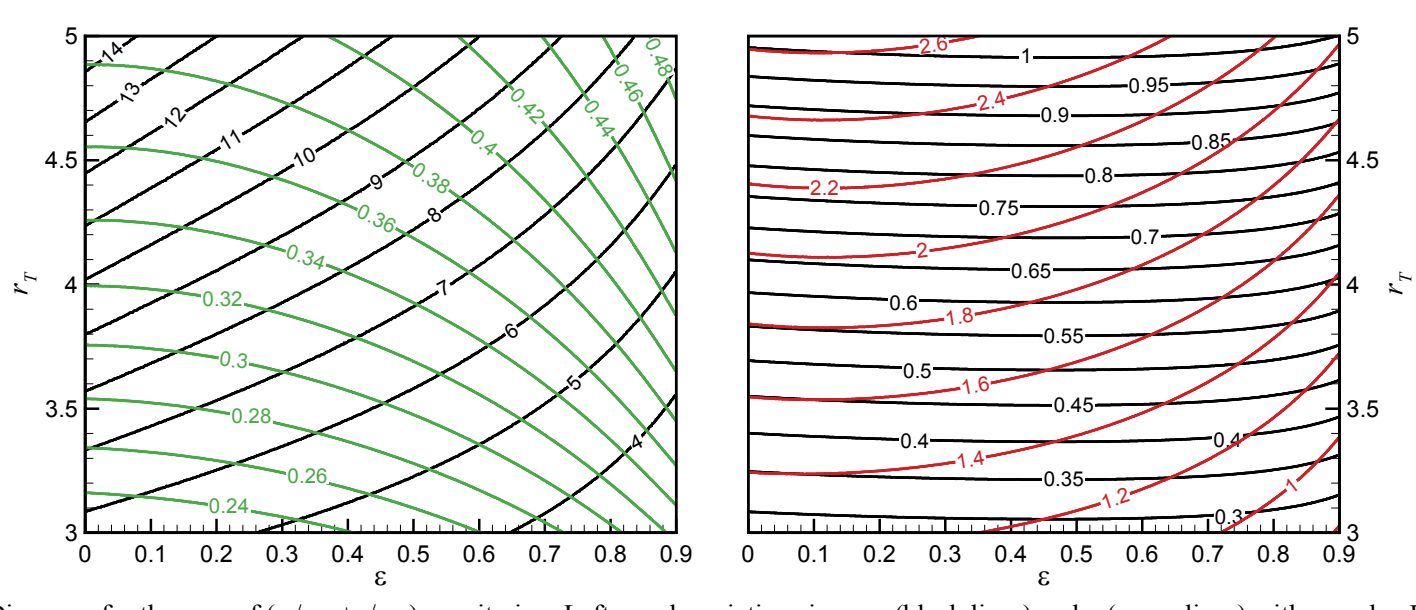

Figure 7 Diagrams for the case of $\left(w / w_{\text {ref }}+\eta / \eta_{\text {ref }}\right)_{\max }$ criterion. Left panel: variations in $r_{p_{-} \text {opt }}$ (black lines) and $\eta$ (green lines) with $r_{\mathrm{T}}$ and $\varepsilon$; Right panel: variations in $w$ (black lines) and $q$ (red lines) with $r_{\mathrm{T}}$ and $\varepsilon$

\subsection{Criterion $\left(w / w_{\text {ref }}+\eta / \eta_{\text {ref }}\right)_{\max }$}

Results for the case when the criterion is $\left(w / w_{\text {ref }}+\eta / \eta_{\text {ref }}\right)_{\max }$ are given in Fig. 7. The meaning of lines in panels is the same as in the previous cases. According to this criterion, the solution with a recuperator is always better than without it.

If we compare the results in Figs. 3, 4, and 7, it can be concluded that the obtained work output according to obtained in the case of $\eta_{\max }$ criterion, and the obtained $\eta$ is always greater than the $\eta$ obtained in the case of $w_{\max }$ criterion.

\section{Conclusions}

From the derived expressions for $w, \eta, q$, and $N_{s}$ and the provided analysis, we can conclude:

- The requirement of maximum thermal efficiency is equivalent to the requirement of minimal entropy generation per work output.

- We have showed that the thermal efficiency of all Brayton cycles with a recuperator, with increasing of $r_{p}$ converge to the thermal efficiency of the Brayton cycle without a recuperator at a certain point defined by $r_{p_{-} \mathrm{A}}$. At this point, the outlet temperature from the compressor is the same as the outlet temperature from the turbine. For small $\varepsilon$, the obtained $\eta_{\max }$ could be smaller than $\eta_{\max }$ obtained without a recuperator. At a certain value of $\varepsilon$ (denoted by $\varepsilon_{\mathrm{B}}$ ), the obtainable $\eta_{\max }$ is the same in both cases, with and without a recuperator. Of course, in the case without a recuperator, a greater $r_{p}$ is required. For the $\varepsilon$ below $\varepsilon_{\mathrm{B}}$, the use of a recuperator is not justified. The value of $\varepsilon_{\mathrm{B}}$ increases with the increase in $r_{\mathrm{T}}$.

- When using the criteria $w_{\max }$ and $\left(w / w_{\text {ref }}+\eta / \eta_{\text {ref }}\right)_{\max }$, the Brayton cycle with a recuperator is always better than without it, regardless of the value of $\varepsilon$. this criterion is always greater than the work output if its effectiveness is less than 0,44 , while at $r_{T}=3,5$ this is the case if its effectiveness is less than 0,2 . Generally, with the increase in $r_{T}$, the recuperator effectiveness at which the installation of the recuperator is justified also increases.

\section{References}

[1] Curzon, F. L.; Ahlborn, B. Efficiency of a Carnot engine at maximum power output. // Am J Phys. 43, (1975), pp. 2224. DOI: $10.1119 / 1.10023$

[2] Leff, H. S. Thermal efficiency at maximum power output: New results for old engines // AmerJ Phys. 55, (1987), pp. 602-610. DOI: 10.1119/1.15071

[3] Ibrahim, O. M.; Klein, S. A.; Mitchell, J. W. Optimum heat-power cycles for specified boundary conditions. // ASME J Eng Gas Turb Power. 113, (1991), pp. 514-521. DOI: $10.1115 / 1.2906271$

[4] Durmayaz, A.; Sogut, O. S.; Sahin, B.; Yavuz, H. Optimization of thermal systems based on finite-time thermodynamics and thermoeconomics. // Progress in Energy and Combustion Science. 30, (2004), pp. 175-217. DOI: 10.1016/j.pecs.2003.10.003

[5] Bejan, A. Theory of heat transfer-irreversible power plants. // Int J Heat Mass Transfer. 31, 6(1988), pp. 1211-1219. DOI: 10.1016/0017-9310(88)90064-6

[6] Salamon, P.; Hoffmann, K. H.; Schubert, S.; Berry, R. S.; Andresen, B. What conditions make minimum entropy production equivalent to maximum power production? // J Non-EquilibThermodyn. 26, (2001), pp. 73-83. DOI: 10.1515/JNETDY.2001.006

[7] Wu, C.; Chen, L.; Sun, F. Performance of a regenerative Brayton Heat Engine. // Energy. 2, 2(1996), pp. 71-76. DOI: 10.1016/0360-5442(95)00097-6

[8] Cheng, C. Y.; Chen, C. K. Power optimization of an endoreversible regenerative Brayton cycle. // Energy. 2, 4(1996), pp. 241-247. DOI: 10.1016/0360-5442(95)00126-3

[9] Medina, A.;Roco, J.M.M.; Hernandez, A.C. Regenerative gas-turbines at maximum-power-density conditions. // J Phys D, 29, (1996), pp. 2802-2805. DOI: 10.1088/00223727/29/11/011

[10] Chen, L.; Sun, F.; Wu, C.; Kiang, R.L. Theoretical analysis of the performance of a regenerative closed cycle Brayton engine with internal irreversibilities. // Energy Convers Manage. 38, (1997), pp. 871-877. DOI: 10.1016/S01968904(96)00090-8

[11] Wang, W.; Chen, L.; Sun, F.; Wu, C. Performance analysis for an irreversible variable temperature heat reservoir closed intercooled regenerated Brayton cycle. // Energy 
Convers Manage. 44, (2003), pp. 2713-2732. DOI: 10.1016/S0196-8904(03)00046-3

[12] Tyagi, S. K.; Chen, G. M.; Wang, Q.; Kaushik, S. C. Thermodynamic analysis and parametric study of an irreversible regenerative-intercooled-reheat Brayton cycle. // International Journal of Thermal Sciences. 45, (2006), pp. 829-840. DOI: 10.1016/j.jithermalsci.2005.10.011

[13] Sanchez-Orgaz, S.; Medina, A.; Calvo Hernandez, A. Thermodynamic model and optimization of a multi-step irreversible Brayton cycle. // Energy Convers Manage. 51, (2010), pp. 2134-2143. DOI: 10.1016/j.enconman.2010.03.006

[14] Ust, Y.; Safa, A.; Sahin, B. Ecological performance analysis of an endoreversible regenerative Brayton heatengine. // ApplEnerg. 80, (2004), pp. 247-260.

[15] Ust, Y.; Sahin, B.; Kodal, A.; Akcay, I. K. Ecological coefficient of performance analysis and optimization of an irreversible regenerative-Brayton heat engine. // ApplEnerg. 83, (2006), pp. 558-572. DOI: 10.1016/j.apenergy.2005.05.009

[16] Durmusoglu, Y.; Ust, Y. Thermodynamic optimization of an irreversible regenerative closed Brayton cycle based on thermoeconomic performance criterion. // Applied Mathematical Modelling. 38, (2014), pp. 5174-5186. DOI: 10.1016/j.apm.2014.04.017

[17] Haseli, Y. Optimization of a regenerative Brayton cycle by maximization of a newly defined second law efficiency. // Energy Convers Manage. 68, (2013), pp. 133-140. DOI: 10.1016/j.enconman.2012.12.033

\section{Authors' addresses}

Prof. dr. sc. Marija Živić

Josip Juraj Strossmayer University of Osijek

Mechanical Engineering Faculty in Slavonski Brod,

Trg Ivane Brlić Mažuranić 2, 35000 Slavonski Brod, Croatia

E-mail: mzivic@sfsb.hr

Prof. dr. sc. Zdravko Virag

University of Zagreb,

Faculty of Mechanical Engineering and Naval Architecture,

Ivana Lučića 5, 10000 Zagreb, Croatia

E-mail: zvirag@fsb.hr

Prof. dr. sc. Antun Galović

University of Zagreb,

Faculty of Mechanical Engineering and Naval Architecture,

Ivana Lučića 5, 10000 Zagreb, Croatia

E-mail: agalovic@fsb.hr 